\title{
Marker assisted pyramiding of stem rust, leaf rust and powdery mildew resistance genes for durable resistance in wheat (Triticum aestivum L.)
}

Vikas Venu Kumaran ${ }^{1 *}$, Sivasamy Murugasamy ${ }^{1}$, Jayaprakash Paramasivan ${ }^{2}, \operatorname{Pramod}_{\text {Prasad }}{ }^{2}$, Subodh Kumar ${ }^{2}$, Subhash Chander Bhardwaj ${ }^{2}$, Geetha Murugan ${ }^{1}$, Nisha Rebekah ${ }^{1}$, Shajitha Paneer $^{1}$ and John Peter ${ }^{1}$

${ }^{1}$ ICAR-Indian Agricultural Research Institute, Regional Station, Wellington 643 231, The Nilgiris, Tamilnadu. ${ }^{2}$ ICAR-Indian Institute of Wheat and Barley Research, Regional Station, Flowerdale, Shimla 171 002, Himachal Pradesh.

Article history:

Received: 21 Feb., 2021

Revised: 26 March, 2021

Accepted: 1 May, 2021

\section{Citation:}

Kumaran VV, S Murugasamy, J Paramasivan, P Prasad, S Kumar, SC Bhardwaj, G Murugan, N Rebekah, S Paneer and J Peter. 2021. Marker assisted pyramiding of stem rust, leaf rust and powdery mildew resistance genes for durable resistance in wheat (Triticum aestivum L.). Journal of Cereal Research 13(1): 38-48. http://doi.org/10.25174/2582$\underline{2675 / 2021 / 110866}$

"Corresponding author: E-mail:physiovikas@gmail.com

(C) Society for Advancement of Wheat and Barley Research

\begin{abstract}
Wheat production is essential for food security. Stem and leaf rust diseases continually pose threat to wheat production. In recent years, climate change and intensive crop cultivation practices are making powdery mildew as a potential threat to wheat production. Deploying resistant cultivars are the most economic, reliable and sustainable way to manage the stem rust, leaf rust and powdery mildew of wheat. Using conventional selection system, it is difficult to select two or more genes in a single genotype. In such a situation, phenotype neutral selection based on marker-trait association along with seedling and adult plant reaction become inevitable. Stem rust, leaf rust and powdery mildew resistance genes, $\operatorname{Sr} 24 / \mathrm{Lr} 24, \mathrm{Sr} 26$ and $\operatorname{Sr} 36 / \mathrm{Pm} 6$ were pyramided in the background of nine Indian wheat cultivars through marker assisted backcross approach. The presence of the rust and powdery mildew resistance genes were confirmed using microsatellite markers such as $\operatorname{Sr} 24 \# 12$ (Sr24/Lr24), Sr26\#43 (Sr26) and Stm773-2 (Sr36/Pm6) in the pyramided lines. Stable lines were selected at $\mathrm{BC}_{3} \mathrm{~F}_{4}$ generation. Seedling and adult plant reaction of pyramided lines showed resistance to most of the stem and leaf rust pathotypes prevailing in India. Using gene pyramids (Sr24/Lr24, Sr26 and Sr36/Pm6) that confer resistance to the predominant pathotypes of stem rust, leaf rust and powdery mildew could impart durability to the cultivars than single gene deployment.
\end{abstract}

Key words: Stem rust, leaf rust, powdery mildew, molecular markers

\section{Introduction}

Wheat is one of the most widely consumed cereal crops worldwide that provides $20 \%$ of dietary calories and protein (Shiferaw et al., 2013). In India, wheat is the most important cereal crop after rice with a production of 107.18 MT during 2019-20 (Third Advanced Estimates, 2020). But with the rapidly increasing population, India will need more than 140 million tons of wheat by 2050 . Among many factors, intensified agricultural practices and climate change have increased the incidence of pathogens in wheat in the recent years. Wheat is affected by various pathogens, amongst which the rusts caused by Puccinia spp. are the most devastating (Chaves et al., 2013). Stem rust caused by Puccinia graminis $\mathrm{f}$. sp. tritici can cause as much as 100\% yield loss (Leonard and Szabo, 2005). Stem rust became a serious concern with the emergence of Ug99 race in East Africa and its migration to middle east, Iran etc. (Singh et al., 2008). This race was able to overcome the widely used stem rust resistance gene $\operatorname{Sr} 31$ (Pretorius et al., 2000) which had protected wheat crop from stem rust for more than two decades. Since 1999, 
pathogen is evolving rapidly resulting in thirteen variant within the Ug99 lineage of wheat stem rust (Rusttracker, 2019). In India, seven million hectares area covering Central and Peninsular India is considered to be stem rust prone (Bhardwaj et al., 2019). Leaf rust caused by Puccinia triticina Eriks is prevalent in all the wheat growing regions of India (Bhardwaj et al., 2019). Yield loss due to leaf rust varies from $15 \%$ to $60 \%$ (McIntosh, 1998). In recent years, powdery mildew of wheat caused by Blumeria graminis f.sp. tritici is gaining attention due to the changing climatic situations and modern cultivation practices. Powdery mildew can result in yield reductions of upto 40\% under humid conditions (Bennett, 1984). In India, powdery mildew is cause of concern for wheat in cooler regions falling under the northwestern plain zone, northern and southern hill zone (Singh et al., 2009). It has been estimated that PM can cause yield losses upto 35\% (Sharma et al., 1996).

Nearly 60, 80 and 58 stem rust, leaf rust and powdery mildew resistance genes, respectively have been cataloged in wheat (Prasad et al., 2020; McIntosh et al., 2017). But the rapid evolution of new virulent races makes most of the genes ineffective (Singh et al., 2015). Hence, deployment of single resistance gene should be avoided as long-term and large-scale cultivation of such resistant varieties result breakdown of resistance and significant shifts in the virulence pattern of the pathogen population. To prevent or delay the breakdown of resistance, pyramiding multiple resistance genes in a single variety is a viable and vital strategy. However, gene pyramiding is difficult using conventional breeding methods. Such limitations of conventional breeding can be overcome using marker assisted pyramiding of rust resistance genes along with seedling and adult plant reaction. Availability and accessibility to closely linked molecular markers of the target genes makes the identification of genotypes with two or three genes possible (Gupta et al., 2009), which can further assist in their pyramiding in single genotype.

Stem rust resistance gene $(S r)$, Sr36, derived from Triticum timopheevii is located in the $2 \mathrm{BS}$ chromosome provides resistance against stem rust pathotypes in India (Tomar and Menon, 2001). Sr36 is also tightly linked to effective powdery mildew resistance gene, Pm6 (Jorgensen and Jensen, 1973). Another Sr gene, Sr26 derived from Agropyron elongatum (Knott, 1961) translocated to chromosome $6 \mathrm{AL}$ remains effective inspite of its large scale utilisation in the 1970s and 1980s (McIntosh et al., 1988). Sr26 is effective gene against $\operatorname{Sr31}$-virulent race Ug99 (TTKSK) and its derivatives (Singh et al., 2011). The Agropyron elongatum derived rust resistance genes Sr24/ Lr24 conferred resistance to leaf and stem rusts for many years against the prevailing pathotypes in India (Tomar et al., 2014). In India, the virulence for Sr24 was first time detected from Wellington (Tamil Nadu) and named 40-1 (62G29-1) (Bhardwaj et al., 1990). This pathotype remained mostly confined to Wellington (Tomar et al., 2014). However, leaf rust resistant gene, Lr24 linked to $\operatorname{Sr} 24$ is still effective against the prevailing leaf rust pathotypes in Indian subcontinent (Prasad et al., 2017).

In the present study, marker assisted pyramiding of stem rust, leaf rust and powdery mildew resistance genes viz., Sr24/Lr24, Sr26 and Sr36/Pm6 in the background of Indian wheat cultivars and their seedling and adult plant reaction are reported.

\section{Materials and methods}

\subsection{Pyramiding of the target genes}

Stem rust resistance gene, $S r 36 / P m 6$ introgressed in the background of nine Indian wheat cultivars viz., HD 2009, HD 2285, HD 2329, HS 240, J24, Kalyansona, Lok 1, MACS 2496 and NI 5439 through backcross breeding method at ICAR- Indian Agricultural Research Institute, (IARI), Regional Station, Wellington, were used as recipient parent (Fig 1). Cook (Cook*6/C80-1), an Australian line reported to carry Triticum timopheevi derived gene $\operatorname{Sr} 36 / \mathrm{Pm} 6$ was used as a donor to transfer Sr36 gene. Darf Kite (Darf*6/3AG3/Kite), an Australian line known to carry $S r 26$ and $S r 24 / L r 24$ was used as donor for transferring this gene into the $\mathrm{Sr} 36 / \mathrm{Pm} 6$ introgressed lines from 2016 onwards. In each generation, agronomic superior and resistance lines were selected and forwarded based on the reaction to stem rust, leaf rust and powdery mildew in the field.

Stable pyramided lines were selected at $\mathrm{BC}_{3} \mathrm{~F}_{4}$ generation on which marker assisted selection was performed to select lines containing either ( $\mathrm{Sr} 36 / \mathrm{Pm} 6$ or $\mathrm{Sr} 26$ or $\mathrm{Sr} 24 / \mathrm{Lr} 24)$ or all the resistance genes ( $\mathrm{Sr} 36 / \mathrm{Pm} 6$, Sr26 and Sr24/Lr24). Pyramided lines were assigned numbers as HW 5061, HW 5062, HW 5063, HW 5064, HW 5065, HW 5066, HW 5067, HW 5068 and HW 5069. 


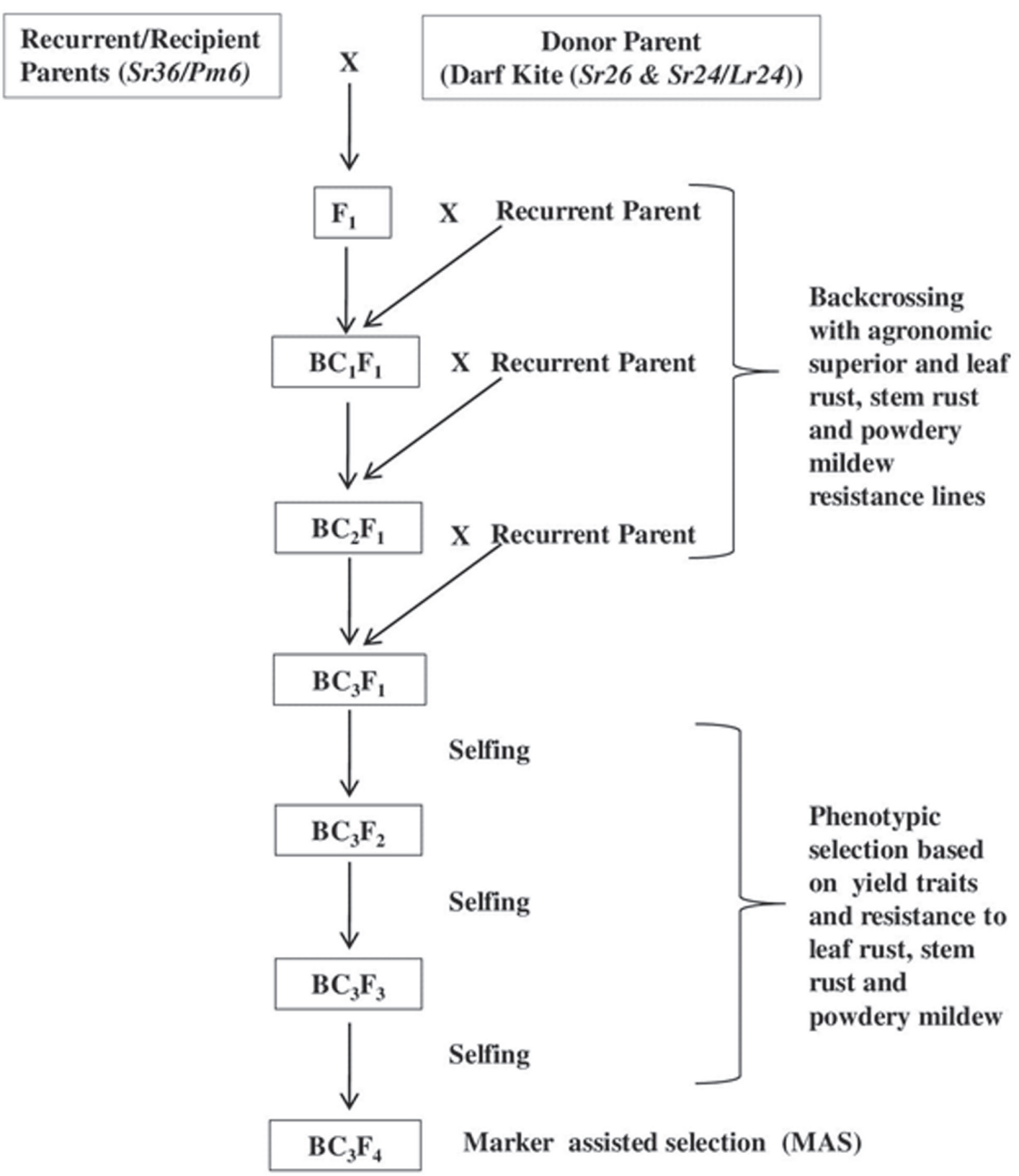

Fig. 1. Schematic representation of transfer of stem rust, leaf rust and powdery mildew resistance genes

\subsection{Screening for stem rust, leaf rust and powdery mildew}

Stable pyramided lines were evaluated for resistance to stem rust, leaf rust and powdery mildew diseases at ICAR- Indian Agricultural Research Institute, (IARI), Regional Station, Wellington in four seasons (Kharif and Rabi) during 2018-19 and 2019-20. Wellington is a natural hotspot for stem rust, leaf rust and powdery mildew diseases. Pyramided lines were planted in one-meter rows of six line each with a spacing of $23 \mathrm{~cm}$ between the rows. Spreader rows of mixture of susceptible cultivars were planted on four sides of the plot and one row of spreader was planted in between the pyramided lines after every 20 rows. All the recommended agronomic practices were followed throughout the crop duration.

Response of pyramided lines to stem and leaf rust diseases was recorded following the modified Cobb scale (Peterson et al., 1948) at three crop growth stage corresponding to Zadoks growth stage (Zadoks et al., 1974) of Z-60 (Begining of anthesis), Z-73 (Early milk stage) and Z-85 to 87 (Soft dough stage). Disease scores were determined by taking into account the severity of disease on plant parts, 
recorded as percentage of area covered (5\%,10\%, 20\%, $40 \%, 60 \%, 80 \%$ and 100\%) and kind of host response as described by Loegering (1959) as 0- No visible infection, R- Resistant: necrotic areas with or without minute uredia, MR- Moderately resistant: small uredia, surrounded by necrotic areas, MX- Intermediate: variable sized uredia, some with necrosis or chlorosis, MS- Moderately susceptible: medium uredia with no chlorosis present, SSusceptible: large uredia, no necrosis or chlorosis.

Stable pyramided lines were also subjected to screening at seedling stage for stem and leaf rust resistance under controlled conditions in the glasshouse at ICAR-Indian
Institute of Wheat and Barley Research (IIWBR), Regional Station, Flowerdale, Shimla where the wheat genotypes were tested with four predominant pathotypes of stem rust viz., 40A (62G29), 40-1(62G29-1), 40-3 (127G29) and 117-6 (37G19) and three pathotypes of leaf rust viz., 77-5 (121R63-1), 77-9 (121R60-1) and 104-2 (21R55). The avirulence/virulence formulae for the pathotypes are provided in Table 1. Seedling tests were performed as per Bhardwaj (2011). Infection types (ITs) on the seedlings were recorded 14 days post inoculation using Stakman scale (Stakman et al., 1962). The Infection types (ITs) 3, $3^{+}$were considered susceptible, whereas lower ITs (' 0 ', ' 1 ', ' 2 ' and ' $\mathrm{X}$ ') were considered as resistant.

Table 1: Avirulence and virulence profile of stem and leaf rust pathotypes

\begin{tabular}{|c|c|c|c|}
\hline $\begin{array}{l}\text { Sl. } \\
\text { No. }\end{array}$ & Pathotypes & Avirulence on genes & Virulence on genes \\
\hline \multicolumn{4}{|c|}{ Stem rust } \\
\hline 1 & $40 \mathrm{~A}(62 \mathrm{G} 29)$ & $\begin{array}{l}\operatorname{Sr} 7 a, 13,21,22,24,25,26,27,30 \\
31,32,33,35,36,37,39,40,43, T m p \\
\text { and } T t 3\end{array}$ & $\begin{array}{l}\text { Sr5, 6, 7b, 8a, 8b, 9a, 9b,9d,9e,9f, 9g, 10, 14, 15, 16, } \\
17,18,19,20,23,28,29,34 \text { and } M c N\end{array}$ \\
\hline 2 & $40-1(62 \mathrm{G} 29-1)$ & $\begin{array}{l}\text { Sr } 7 a, 13,21,22,25,26,27,30,31,32, \\
33,35,36,37,39,40,43, \operatorname{Tm} p \text { and } \\
\text { Tt3 }\end{array}$ & $\begin{array}{l}\text { Sr5, 6, 7b, } 8 a, 8 b, 9 a, 9 b, 9 d, 9 e, 9 f, 9 g, 10,14,15,16 \\
17,18,19,20,23,24,28,29,34 \text { and } M c N\end{array}$ \\
\hline 3 & $40-3(127 \mathrm{G} 29)$ & $\begin{array}{l}\text { Sr 21, 22, 24,25, 26, 27, 30,31, 32, 33, } \\
\text { 35, 36, 37, 39, 40, 42, 43, Tmp and } \\
\text { Tt3 }\end{array}$ & $\begin{array}{l}\text { Sr5, 6, 7a, 7b, } 8 a, 8 b, 9 a, 9 b, 9 d, 9 e, 9 f, 9 g, 10,11,14 \\
15,16,17,18,19,20,23,28,29,30,34,38,44, M c N \\
\text { and } G t\end{array}$ \\
\hline 4 & $117-6$ (37G19) & $\begin{array}{l}\operatorname{Sr} 5,8 a, 8 b, 9 b, 22,24,25,26,27,28 \\
30,31,32,33,35,36,37 \text { and } \operatorname{Tmp}\end{array}$ & $\begin{array}{l}\text { Sr 6, 7a, } 7 b, 9 e, 9 f, 9 g, 10,11,12,13,14,15,16,17,19 \\
21,23,29,34 \text { and } M c N\end{array}$ \\
\hline \multicolumn{4}{|c|}{ Leaf rust } \\
\hline 5 & 77-5(121R63-1) & $\begin{array}{l}\operatorname{Lr} 9,19,24,25,28,29,32,39,42,43, \\
45 \text { and } 47\end{array}$ & $\begin{array}{l}\operatorname{Lr} 1,2 a, 2 b, 2 c, 3,10,11,12,13,14 a, 14 b, 15,16,17 a, 17 b, \\
18,20,21,22 a, 22 b, 23,26,27,30,33,35,36,37,38, \\
40,44,48 \text { and } 49\end{array}$ \\
\hline 6 & $77-9(121 \mathrm{R} 60-1)$ & $\begin{array}{l}\operatorname{Lr} 2 a, 2 b, 2 c, 9,19,24,25,28,32,39 \\
42,45 \text { and } 47\end{array}$ & $\begin{array}{l}\operatorname{Lr} 1,3,10,11,12,13,14 a, 14 b, 15,16,17 a, 17 b, 18,20 \\
21,22 a, 22 b, 23,26,27+31,30,33,35,36,37,38,44, \\
46,48 \text { and } 49\end{array}$ \\
\hline 7 & 104-2(21R55) & $\begin{array}{l}\operatorname{Lr} 9,10,13,15,19,20,24,25,28,29 \\
32,36,39,42,43,45 \text { and } 47\end{array}$ & $\begin{array}{l}\operatorname{Lr} 1,2 a, 2 b, 2 c, 3,11,12,14 a, 14 b, 16,17 a, 17 b, 18,21, \\
22 a, 22 b, 23,26,27+31,30,33,34,35,37,38,40,44, \\
48 \text { and } 49\end{array}$ \\
\hline
\end{tabular}

Powdery mildew reaction was recorded as per the scale $(0$ 9) devised by Saari and Prescott (1975) for scoring the foliar disease intensity. Lines were scored for powdery mildew at dough stage (Zadoks growth stage of 83-87) (Zadoks et al., 1974). Disease reactions of 10 randomly selected lines were averaged to get the final score. Disease score upto 5 was considered as resistant while $>5$ as susceptible.

\subsection{DNA extraction, molecular markers analyses}

DNA was extracted from approximately $100 \mathrm{mg}$ of fresh leaves collected from 20 days old seedlings. DNA isolation was carried out using CTAB method of Doyle and Doyle (1990). DNA was quantified on 1\% agarose gel. The diluted DNA samples were used for PCR analysis.

Microsatellite markers stm773-2 linked to Sr36 (Tasilo et al., 2008), Sr26\#43 (Mago et al., 2005) linked to Sr26 and Sr24\#12 (Mago et al., 2005) linked to Sr24/Lr24 were used to perform marker assisted selection. The sequences of the primers with the amplicon are given in Table 2. 
Table 2: Details of Primer sequences for DNA markers linked to rust resistance genes in wheat

\begin{tabular}{|c|c|c|c|c|}
\hline Gene & Marker & Sequence of primer & Size of the amplicon (bp) & Reference \\
\hline $\begin{array}{l}\text { Sr36/ } \\
\text { Pm6 }\end{array}$ & $\begin{array}{l}\text { stm } 773-2 F \\
\operatorname{stm} 773-2 R\end{array}$ & $\begin{array}{l}\text { ATG GTT TGT TGT GTT GTG TGT AGG } \\
\text { AAA CGC CCC AAC CAC CTC TCT C }\end{array}$ & $155 \mathrm{bp}$ & Tsilo et al., 2008 \\
\hline $\operatorname{Sr} 26$ & $\begin{array}{l}\operatorname{Sr} 26 \# 43-F \\
\operatorname{Sr} 26 \# 43-R\end{array}$ & $\begin{array}{l}\text { AAT CGT CCA CAT TGG CTT CT } \\
\text { CGC AAC AAA ATC ATG CAC TA }\end{array}$ & $207 \mathrm{bp}$ & Mago et al., 2005 \\
\hline $\begin{array}{l}S r 24 / \\
L r 24\end{array}$ & $\begin{array}{l}\text { Sr24\# } 12-F \\
\text { Sr24\# } 12-R\end{array}$ & $\begin{array}{c}\text { CAC CCG TGA CAT GCT CGT A } \\
\text { AAC AGG AAA TGA GCA ACG ATG T }\end{array}$ & $500 \mathrm{bp}$ & Mago et al., 2005 \\
\hline
\end{tabular}

Polymerase chain reaction was performed in $20 \mu \mathrm{l}$ reaction volume containing 50-75 $\mathrm{ng}$ of template DNA, $250 \mathrm{nM}$ of each primer (forward and reverse), $0.2 \mathrm{nM}$ of each dNTPs, $2 \mu \mathrm{l}$ of 10X Taq buffer and 1 unit of Taq DNA polymerase. PCR reaction was performed in Applied Biosciences (Veriti) thermo cycler using the following PCR conditions with little modifications. PCR condition for $\operatorname{Sr} 24 \#$ 12: one 3-min cycle at $94^{\circ} \mathrm{C}$ (initial denaturation), followed by 35 cycles of $45 \mathrm{~s}$ at $94^{\circ} \mathrm{C}$ (denaturation), $45 \mathrm{~s}$ at $65^{\circ} \mathrm{C}$ (annealing) and 1 min at $72^{\circ} \mathrm{C}$ and a final extension at $72^{\circ} \mathrm{C}$ for $10 \mathrm{~min}$. Sr26\#43: one 3-min cycle at $94^{\circ} \mathrm{C}$ (initial denaturation), followed by 30 cycles of $30 \mathrm{~s}$ at $94^{\circ} \mathrm{C}$ (denaturation), $30 \mathrm{~s}$ at $55^{\circ} \mathrm{C}$ (annealing) and $45 \mathrm{~s}$ at $72^{\circ} \mathrm{C}$ and a final extension at $72^{\circ} \mathrm{C}$ for $10 \mathrm{~min}$. $\operatorname{stm} 773$-2: one 1 -min cycle at $95^{\circ} \mathrm{C}$ (initial denaturation), followed by 35 cycles of $30 \mathrm{~s}$ at $95^{\circ} \mathrm{C}$ (denaturation), $30 \mathrm{~s}$ at $55^{\circ} \mathrm{C}$ (annealing) and $1 \mathrm{~min}$ at $72^{\circ} \mathrm{C}$ and a final extension at $72^{\circ} \mathrm{C}$ for $10 \mathrm{~min}$. The amplified products were resolved in $2 \%$ agarose gel and visualized under the gel documentation system (Syngene, Gene Genius bioimaging system, UK).

\section{Results and Discussion}

Pyramiding of rust resistance genes in the elite genetic background is one of the most important strategies to develop durable rust resistant wheat varieties. Providing genetic/host resistance through pyramiding of stem rust, leaf rust and powdery mildew ( $\operatorname{Sr} 36 / \mathrm{Pm} 6, \operatorname{Sr} 26, \operatorname{Sr} 24 / \mathrm{Lr} 24)$ resistance genes will be an effective strategy to combat the threats from stem rust, leaf rust and powdery mildew in India. Pyramiding of two or more resistance genes into a single background has been prominently assisted by the development of molecular markers and confirmed through the host pathogen interaction at seedling adult plant stage, which otherwise will be time consuming through conventional breeding approaches.
Lines carrying Sr36/Pm6 gene were pyramided with stem and leaf rust resistance genes, $\operatorname{Sr} 26$ and $S r 24 / L r 24$ and the $\mathrm{F}_{1} \mathrm{~s}$ were backcrossed for three generations with the respective recurrent parents and subsequent selfing for four generations. In $\mathrm{F}_{2}$ and subsequent generations, phenotypic selection of lines resistant to stem rust, leaf rust and powdery mildew along with high yielding traits (number of productive tillers, panicle length, number of spikelets and grains per panicle etc.) were followed. High yielding and disease resistant lines were forwarded to select stable pyramided lines at $\mathrm{BC}_{3} \mathrm{~F}_{4}$ generation. Molecular marker confirmation of stem and leaf rust and powdery mildew (Sr36/Pm6, Sr26, Sr24/Lr24) resistance genes were performed in the stable pyramided lines.

Molecular marker analysis using the microsatellite markers for stem/leaf rust resistance gene, Sr24\# 12 displayed $500 \mathrm{bp}$ amplicon in all the backgrounds, indicating the presence of $S r 24 / L r 24$ gene (Fig 2 (A1A2)). In case of stem rust resistance gene, $\operatorname{Sr} 26$, all the pyramided lines showed the presence of the gene with 207 bp amplicon (Fig 2 (B1-B2)). Whereas, stm773-2, a co-dominant marker linked to stem rust and powdery mildew resistance gene, $\operatorname{Sr} 36 / \mathrm{Pm} 6$ revealed a $155 \mathrm{bp}$ amplicon in the homozygous lines positive for $\mathrm{Sr} 36$ and a $190 \mathrm{bp}$ amplicon in the homozygous lines negative for Sr36. Both the amplicons were present in the heterozygous lines. Among the nine pyramided lines, two lines (HW 5067 and HW 5068) showed a clear homozygous band of $155 \mathrm{bp}$ indicating the presence of Sr36/Pm6 gene, while three lines (HW 5062, HW 5063 and HW 5069) were heterozygous showing both 155 and 190 bp product (Fig 3 (C1-C2)) and remaining lines were negative for $\operatorname{Sr} 36 / \mathrm{Pm} 6$ gene. The marker score of the pyramided lines along with the donor and recurrent parents are presented in Table 3. 
Marker assisted pyramiding of stem rust, leaf rust and powdery mildew resistance genes

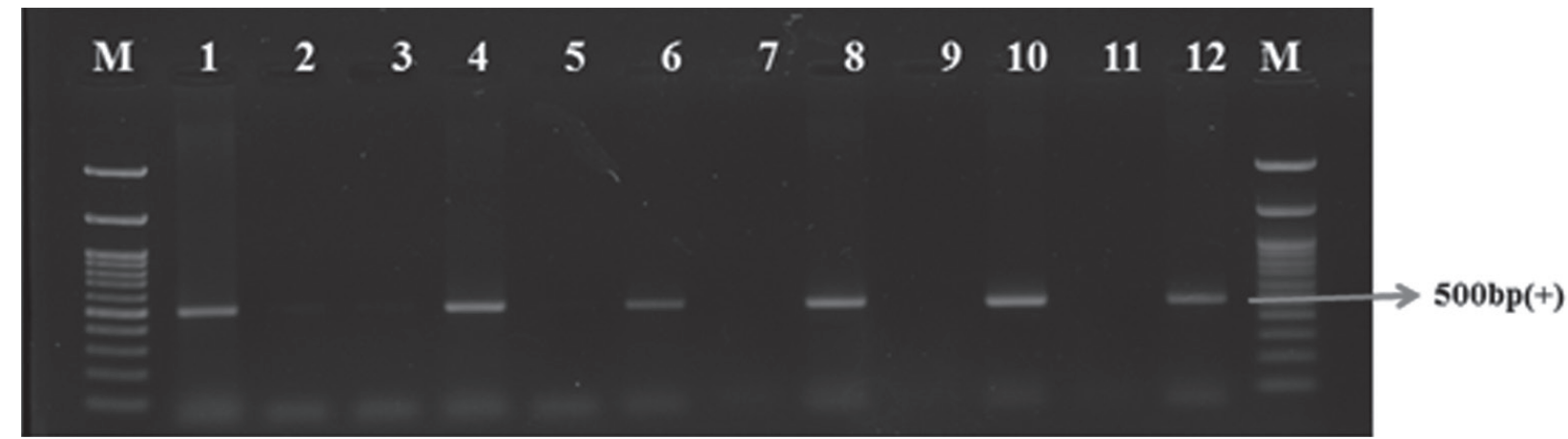

(A1)

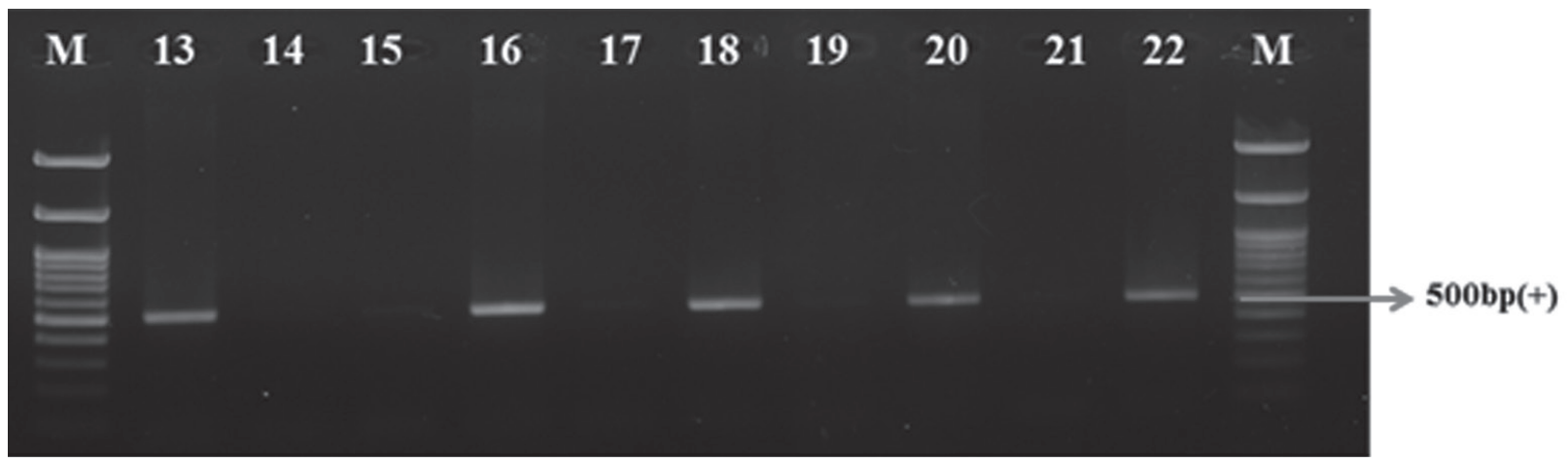

(A2)

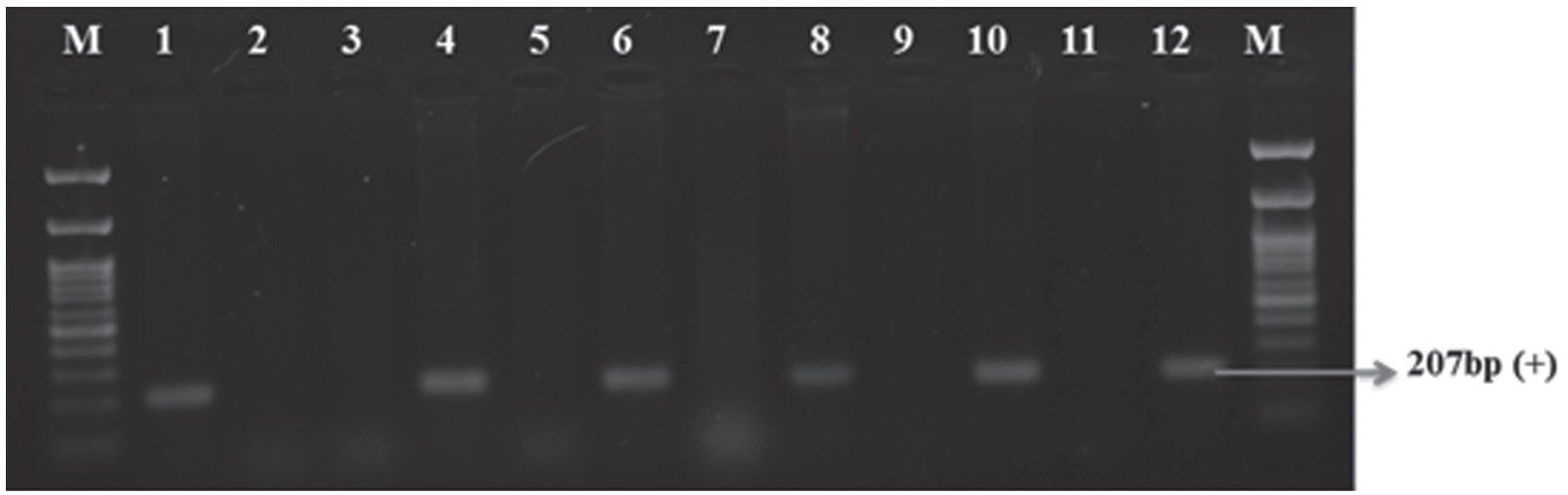

(B1)

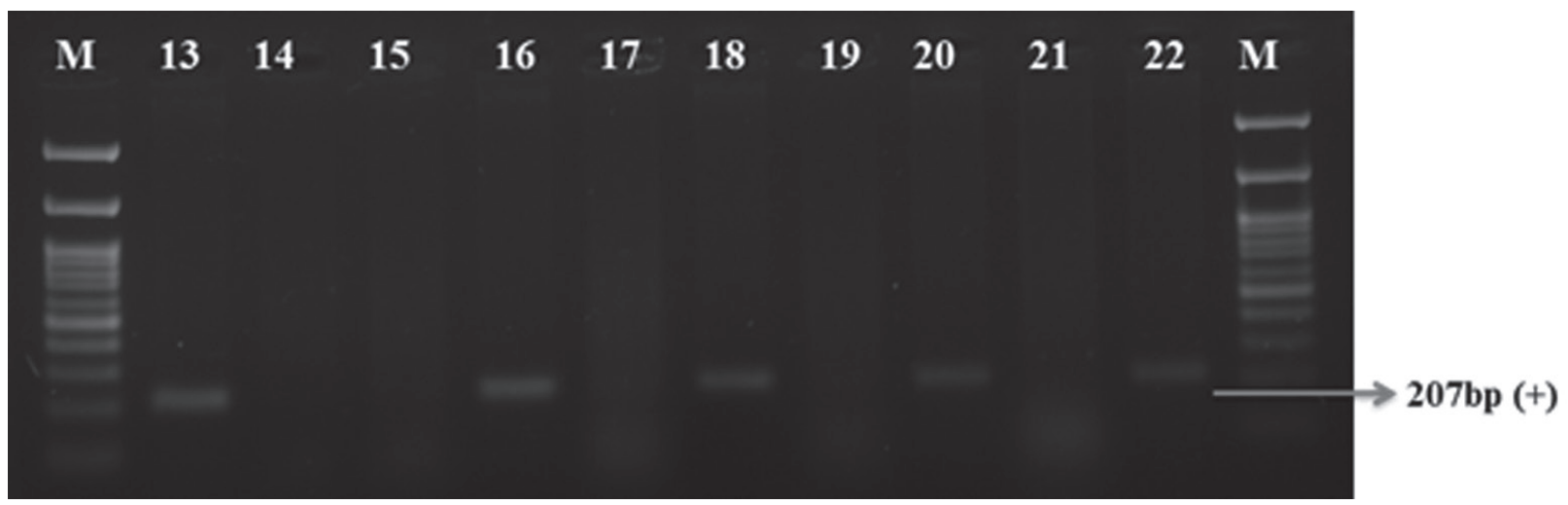

(B2)

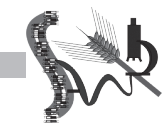




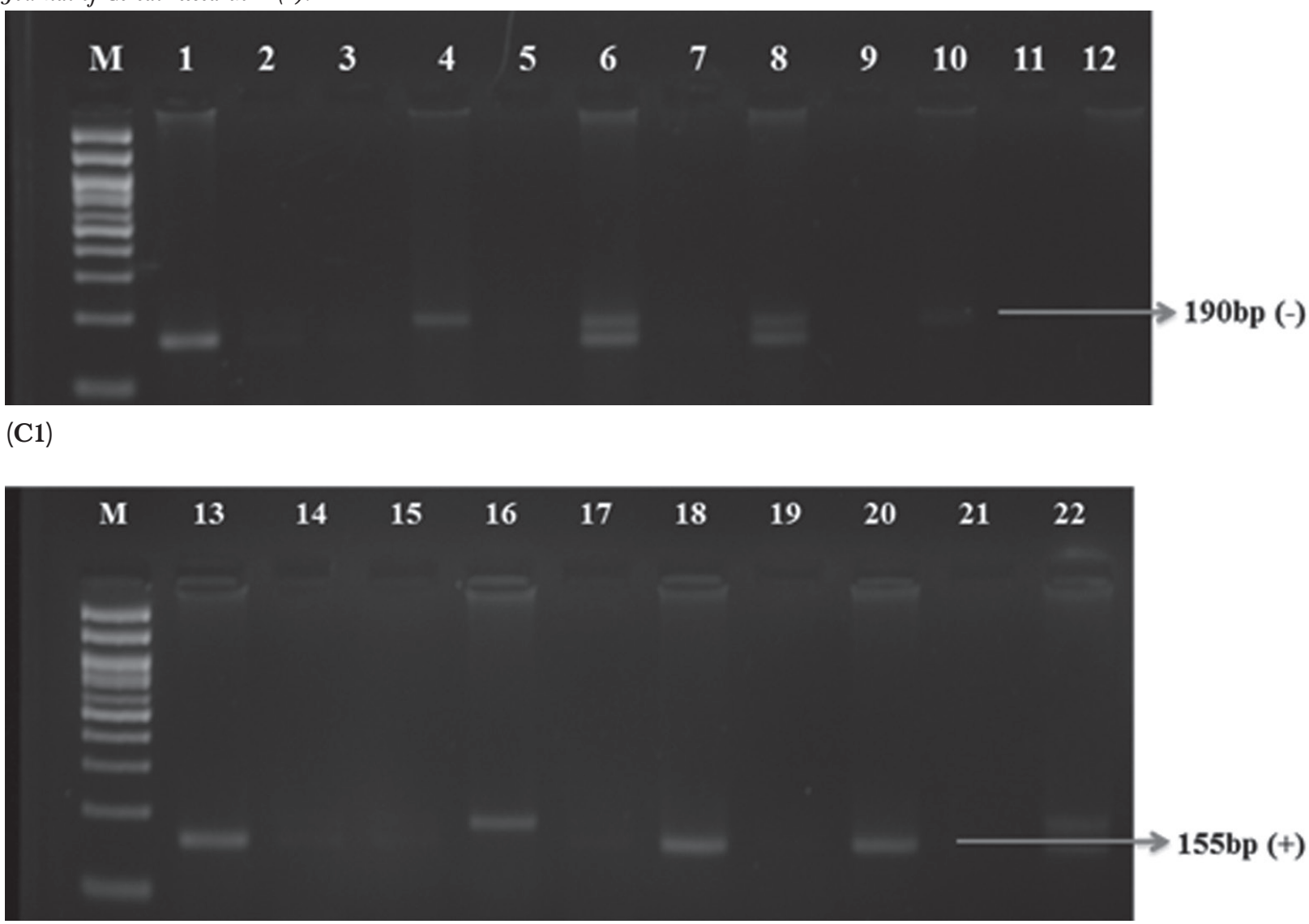

(C2)

Fig 2 Molecular marker confirmation of stem rust/leaf rust/powdery mildew resistance gene, Sr24 (Sr24\#12) (A1-A2), Sr26 (Sr26\#43) (B1-B2), Sr36/Pm6 (stm773-2) (C1-C2) in pyramided lines

A1-A2:1\&13- Darf Kite (Positive Control); 2\&14-Lok1 (Negative Control); B1-B2: 1\&13-Darf Kite (Positive Control); 2\&14Sonalika (Negative Control); C1-C2:1\&13- Cook (Positive Control); 2\&14- Sonalika (Negative Control); AI-A2, B1-B2 and C1-C2: M (100bp Ladder); 3-HD 2009; 4-HW 5061; 5-HD 2285; 6-HW 5062; 7-HD2329; 8-HW 5063; 9-HS 240; 10-HW 5064; 11-J 24; 12-HW 5065; 15-Kalyansona; 16-HW 5066; 17-Lok-1; 18-HW 5067; 19-MACS 2496; 20-HW 5068; 21-NI 5439; 22-HW 5069.

Table 3: Presence/absence of stem rust, leaf rust and powdery mildew resistance genes in pyramided lines using respective linked markers

\begin{tabular}{ccccc}
\hline S1. No. & $\begin{array}{c}\text { Donors/ Recurrent parent/ } \\
\text { Pyramided lines }\end{array}$ & $\begin{array}{c}\text { Sr24/Lr24 } \\
(\text { Sr24\# 12) }\end{array}$ & $\begin{array}{c}\text { Sr26 } \\
(\text { Sr26\#43) }\end{array}$ & $\begin{array}{c}\text { Sr36/Pm6 } \\
\text { (Stm733-2) }\end{array}$ \\
\hline 1 & HD 2009 & - & - & - \\
2 & HW 5061 & + & + & - \\
3 & HD 2285 & - & - & + \\
4 & HW 5062 & + & + & - \\
5 & HD 2329 & - & - & $+/-$ \\
6 & HW 5063 & + & + & - \\
7 & HS 240 & - & - & - \\
8 & HW 5064 & + & + & - \\
9 & J 24 & - & - & - \\
10 & HW5065 & + & + & - \\
11 & Kalyansona & - & & - \\
\hline
\end{tabular}




\begin{tabular}{|c|c|c|c|c|}
\hline 12 & HW 5066 & + & + & - \\
\hline 13 & Lok-1 & - & - & - \\
\hline 14 & HW 5067 & + & + & + \\
\hline 15 & MACS 2496 & - & - & - \\
\hline 16 & HW 5068 & + & + & + \\
\hline 17 & NI 5439 & - & - & - \\
\hline 18 & HW 5069 & + & + & $+/-$ \\
\hline 19 & $\begin{array}{l}\text { Darf Kite (Positive control) } \\
\text { (Donor for Sr26 } \mathcal{E}^{2} \text { Sr24/Lr24) }\end{array}$ & + & + & - \\
\hline 20 & $\begin{array}{l}\text { Cook (Positive control) } \\
\text { (Donor for Sr36) }\end{array}$ & - & - & + \\
\hline 21 & $\begin{array}{c}\text { Sonalika } \\
\text { (Negative control) }\end{array}$ & - & - & - \\
\hline 22 & Lok1(Negative control) & - & - & - \\
\hline
\end{tabular}

Among the nine genotypes used for pyramiding, only two pyramided lines, HW 5067 and HW 5068 in the background of Lok 1 and MACS 2496 respectively were confirmed to carry all the stem rust, leaf rust (Sr36/Pm6, Sr26 and Sr24/ Lr24) and powdery mildew (Sr36/Pm6) resistance genes, while the rest of the pyramided lines showed the presence of stem and leaf rust (Sr26 and Sr24/Lr24) and absence of stem and powdery mildew resistance genes ( $\mathrm{Sr} 36 / \mathrm{Pm} 6)$. However, all the stable lines negative for stem rust and powdery mildew (Sr36/Pm6) gene showed resistance reaction to powdery mildew compared to their respective recurrent parent. This may be due to the partial/incomplete expression of the gene in those genetic backgrounds.

Stable pyramided lines were subjected to field screening for four seasons in two years. Pyramided lines carrying either Sr26, Sr36/Pm6 and Sr24/Lr24 or Sr26 and Sr24/Lr24 were resistant to both stem and leaf rusts in comparison to the recurrent parents which were susceptible with a stem rust score ranging from $20 \mathrm{~S}$ to $60 \mathrm{~S}$ and leaf rust from $40 \mathrm{~S}$ to $80 \mathrm{~S}$ (Table 4). Stem and leaf rust resistance genes have imparted resistance which got reflected in the resistance reaction of the pyramided lines. Pyramided lines (HW 5067 and HW 5068) with powdery mildew resistance gene $(S r 36 / P m 6)$ showed immune reaction, to powdery mildew, while rest of the lines without $\operatorname{Sr} 36 / \mathrm{Pm} 6$ also remained resistant (score ranging from 3 to 4 ) compared to their recurrent parent (Table 4). Partial/incomplete expression of the gene in those genetic backgrounds might have caused the discrepancies between the phenotype and genotype.

Table 4: Stem and leaf rust response of the parental and pyramided lines at seedling and adult plant stage and powdery mildew at adult plant stage

\begin{tabular}{llccccccccccc}
\hline $\begin{array}{c}\text { Sl. } \\
\text { No. }\end{array}$ & $\begin{array}{c}\text { Donors/ } \\
\text { Recurrent } \\
\text { parent/ } \\
\text { Pyramided lines }\end{array}$ & \multicolumn{3}{c}{$\begin{array}{c}\text { Seedling response to stem } \\
\text { rust pathotypes }\end{array}$} & $\begin{array}{c}\text { Seedling response to } \\
\text { leaf rust pathotypes }\end{array}$ & \multicolumn{3}{c}{ Adult plant response } \\
\cline { 2 - 13 } & $\mathbf{4 0}$ & $\mathbf{4 0 - 1}$ & $\mathbf{4 0 - 3}$ & $\mathbf{1 1 7 - 6}$ & $\mathbf{7 7 - 5}$ & $\mathbf{7 7 - 9}$ & $\mathbf{1 0 4 - 2}$ & $\begin{array}{c}\text { Stem } \\
\text { rust }\end{array}$ & $\begin{array}{c}\text { Leaf } \\
\text { rust }\end{array}$ & $\begin{array}{c}\text { Powdery } \\
\text { mildew }\end{array}$ \\
\hline 1 & HD 2009 & 3 & 3 & $3+$ & $;$ & $3+$ & $3+$ & $3+$ & $40 S^{*}$ & $40 \mathrm{~S}$ & 5 \\
2 & HW 5061 & 1 & $; 1$ & $1+$ & $;$ & $0 ;$ & $0 ;$ & $0 ;$ & $\mathrm{F}$ & $\mathrm{F}$ & 3 \\
3 & HD 2285 & 3 & 3 & $2-$ & $;$ & $3+$ & $3+$ & $3+$ & $40 \mathrm{~S}$ & $60 \mathrm{~S}$ & 6 \\
4 & HW 5062 & $; 1$ & $; 1$ & 1 & $0 ;$ & 0 & 0 & 0 & $\mathrm{~F}$ & $\mathrm{~F}$ & 3 \\
5 & HD 2329 & $3+$ & 3 & $0 ;$ & $;$ & $3+$ & $3+$ & $3+$ & $40 \mathrm{~S}$ & $60 \mathrm{~S}$ & 6 \\
6 & HW 5063 & 2 & $; 1$ & $1+$ & $;$ & 0 & 0 & 0 & $\mathrm{~F}$ & $\mathrm{~F}$ & 4 \\
7 & HS 240 & $2-$ & 2 & $0 ;$ & $2-$ & 2 & $3+$ & $3+$ & $20 \mathrm{~S}$ & $60 \mathrm{~S}$ & 6 \\
\hline
\end{tabular}




\begin{tabular}{llcccccccccc}
\hline 8 & HW 5064 & 1 & $; 1$ & $; 1$ & 1 & $0 ;$ & $0 ;$ & $0 ;$ & $\mathrm{F}$ & $\mathrm{F}$ & 4 \\
9 & J 24 & $2-$ & 3 & 2 & 2 & $3+$ & $3+$ & $3+$ & $40 \mathrm{~S}$ & $40 \mathrm{~S}$ & 6 \\
10 & HW 5065 & $;$ & 0 & $0 ;$ & $;$ & 0 & 0 & 0 & $\mathrm{~F}$ & $\mathrm{~F}$ & 4 \\
11 & Kalyansona & $3+$ & $3+$ & $2+$ & $;$ & $3+$ & 2 & $3+$ & $60 \mathrm{~S}$ & $80 \mathrm{~S}$ & 6 \\
12 & HW 5066 & 2 & $; 1$ & 1 & $;$ & $;$ & 0 & $;$ & $\mathrm{F}$ & $\mathrm{F}$ & 4 \\
13 & Lok 1 & $3+$ & $3+$ & $3+$ & 3 & $3+$ & $3+$ & $3+$ & $60 \mathrm{~S}$ & $60 \mathrm{~S}$ & 6 \\
14 & HW 5067 & $;$ & 0 & $0 ;$ & $;$ & 0 & 0 & $;$ & $\mathrm{F}$ & $\mathrm{F}$ & 0 \\
15 & MACS 2496 & $2-$ & $2-$ & $; 1$ & $;$ & $3+$ & $3+$ & $3+$ & $20 \mathrm{~S}$ & $40 \mathrm{~S}$ & 5 \\
16 & HW 5068 & 0 & $0 ;$ & $0 ;$ & $;$ & 0 & 0 & 0 & $\mathrm{~F}$ & $\mathrm{~F}$ & 0 \\
17 & NI 5439 & $3+$ & $3+$ & $0 ;$ & $3+$ & $3+$ & $3+$ & $3+$ & $60 \mathrm{~S}$ & $80 \mathrm{~S}$ & 7 \\
18 & HW 5069 & 2 & 1 & 1 & $; 1$ & $0 ;$ & $0 ;$ & $;-$ & $\mathrm{F}$ & $\mathrm{F}$ & 3 \\
19 & Darf Kite & $;$ & 0 & $; 1$ & 1 & $0 ;$ & 0 & $0 ;$ & $\mathrm{F}$ & $\mathrm{F}$ & 2 \\
& $\begin{array}{l}\text { (Donor for Sr26 E } \\
\text { Sr24/Lr24) }\end{array}$ & & & & & & & & & & \\
20 & Cook & 0 & $0 ;$ & $;$ & $;$ & - & - & - & $\mathrm{F}$ & - & 0 \\
& $\begin{array}{l}\text { (Donor for Sr36/ } \\
\text { Pm6) }\end{array}$ & & & & & & & & & \\
\hline
\end{tabular}

*S-Susceptible; F-Free

Pyramided lines were also evaluated at seedling stage under glass house condition using prevalent pathotypes of stem (40A, 40-1, 40-3 and 117-6) and leaf rust (77-5, 77-9 and 104-2). These lines irrespective of the presence of two ( $\operatorname{Sr} 26$ and $\operatorname{Sr} 24 / L r 24)$ or three (Sr26, Sr36/Pm6 and Sr24/Lr24) stem rust resistance genes displayed resistant reaction to all the pathotypes relative to recurrent parent which showed susceptible reaction to most of the pathotypes. Similar was the case for leaf rust pathotypes wherein all the pyramided lines were resistant due to the presence of leaf rust resistant gene, $L r 24$ and the recurrent parent exhibited susceptible reaction. Seedling response of the pyramided lines to stem and leaf rust are presented in Table 4.

Pyramiding of resistance genes is one of the most promising approaches to enhance the effectiveness and durability of a gene and cultivars (Brown, 2015). Many of the resistance genes derived from alien sources have linkage drag in the form of yield penalty, quality traits etc., a common phenomenon in resistance breeding (Tomar and Menon, 2001). However, use of genetic stocks in elite background, growing large number of segregating lines in $\mathrm{F}_{2}$ and use of closely linked/functional marker could limit the linkage drag to a greater extent. Stem rust resistance gene, Sr36/Pm 6 had been used in the development of cultivars and improved germplasm in North America, Australia, South Africa, Kenya and Ethiopia (McIntosh $e t$ al., 1995). Similarly, Sr36/Pm6 transferred to durum wheat cultivar, HI8498 provided near immune reaction to many pathotypes belonging to 117 group (Sai Prasad et al., 2014). Stem/leaf rust resistance gene, $\operatorname{Sr} 24 / \operatorname{Lr} 24$ has been used extensively in the development and release of several wheat varieties in India. Although, pathotype (40-1) virulent on Sr24has been reported from India which is mostly confined to Wellington, Sr24/Lr24 continues to provide resistance and does not affect yield (Tomar et al., 2014).

Stem rust resistance gene, Sr26 used in Australia for the development of stem rust resistance cultivars, although it had yield penalty (The et al., 1988, McIntosh et al., 1995). Yield reduction was not observed in the pyramided lines with $\operatorname{Sr} 26$. In our study, linkage drag in the form of yield penalty was not observed in the pyramided lines either in two gene ( $S r 26$ and $S r 24 / L r 24)$ or three gene ( $S r 26$, Sr36/Pm6 and Sr24/Lr24) combinations as selections were carried out for both yield traits (data not shown) and rust resistance in each generation.

Combining multiple resistance genes in a single genotype is more time consuming and laborious through conventional breeding approach because the dominant nature of resistance genes makes it is difficult to distinguish between the presence of single and multiple genes. But this problem is solved to great extend using molecular marker assays (Gupta et al., 2010). Pyramided lines provided resistance to the predominant stem and leaf rust 
Marker assisted pyramiding of stem rust, leaf rust and powdery mildew resistance genes

pathotypes prevailing in India. Combination of resistance genes (Sr24/Lr24, Sr26 and Sr36/Pm6) in the genetic background of cultivars will serve as a good source of resistance which can be strategically deployed to provide durability to resistance.

\section{Acknowledgements}

Authors thank Director and Joint Director (Research), ICAR- Indian Agricultural Research Institute, (IARI), New Delhi for constant encouragements and support.

\section{Conflict of Interest}

Authors declare that they have no conflict of interest.

\section{Ethical Compliance Statement}

NA

\section{Author's Contribution}

Conceptualization of research (VVK); Designing of the experiments (VVK, SM, JP); Contribution of experimental materials (VVK, SM, JP); Execution of field/lab experiments and data collection (VVK, PP, KS, SCB, GM, NR, SP, JP); Analysis of data and interpretation (VVK, SM, JP, SCB); Preparation of the manuscript (VVK, MS, JP, SCB).

\section{References}

1. Bennett FGA. 1984. Resistance to powdery mildew in wheat: a review of its use in agriculture and breeding programmes. Plant Pathology 33: 279-300.

2. Bhardwaj SC, GP Singh, OP Gangwar, P Prasad and S Kumar. 2019. Status of wheat rust research and progress in rust management-Indian context. Agronomy 9: 892

3. Bhardwaj SC. 2011. Resistance genes and adult plant rust resistance of released wheat varieties of India. Research Bulletin 5:31.

4. Brown JK. 2015. Durable resistance of crops to disease: A Darwinian perspective. Annual Review of Phytopathology 53: 513-539.

5. Chaves MS, JA Martinelli, C Wesp-Guterres, FAS Graichen, SP Brammer, SM Scagliusi, PR da Silva, P Wiethölter, GAM. Torres, EY Lau, L Consoli and ALS Chaves. 2013. The importance for food security of maintaining rust resistance in wheat, Food Security 5: $157-176$.
6. Doyle JJ and JL Doyle. 1990. Isolation of plant DNA from fresh tissue. Focus 12: 13-15.

7. Gupta PK, J Kumar, RR Mir and A Kumar. 2010. Marker-assisted selection as a component of conventional plant breeding. Plant Breeding Review 33: 145-217.

8. Gupta PK, P Langridge and RR Mir. 2009. Markerassisted wheat breeding: present status and future possibilities. Molecular Breeding 26:145-161.

9. Status summary: Ug99 Lineage. 2019. https:// rusttracker.cimmyt.org. Accessed on 01.02.2021.

10. Jorgensen JH and CJ Jensen. 1973. Gene Pm6 for resistance to powdery mildew in wheat. Euphytica 22: 4-23.

11. Knott DR. 1961.The inheritance of rust resistance. VI. The transfer of stem rust resistance from Agropyron elongatum to common wheat. Canadian Journal of Plant Science 41:109-123.

12. Leonard J and J Szabo. 2005. Stem rust of small grains and grasses caused by Puccinia graminis. Molecular plant pathology 6(2): 99-111.

13. Mago R, HS Bariana, IS Dundas, W Spielmeyer, GJ Lawrence, AJ Pryor and JG Ellis.2005. Development of PCR markers for the selection of wheat stem rust resistance genes $\mathrm{Sr} 24$ and $\mathrm{Sr} 26$. Theoretical and Applied Genetics 111: 496-504.

14. McIntosh RA, J Dubcovsky, WJ Rogers, C Morris and XC Xia. 2017. Catalogue of Gene Symbols for Wheat: 2017 Supplement. Komugi Wheat Genet. Resour. Database. pp 20. Available online at: https:// shigen.nig.ac.jp/wheat/komugi/genes/macgene/ supplement2017.pdf (accessed on 01.02.2021).

15. McIntosh RA, J Dubcovsky, WJ Rogers, CF Morris, R Appels and XC Xia. 2012. Catalogue of gene symbols for wheat: 2012 supplement. Annual Wheat Newsletter 58: 259-279.

16. McIntosh RA. 1998. Breeding wheat for resistance to biotic stress. Euphytica 100: 19-34.

17. McIntosh RA, CR Wellings and RF Park. 1995. Wheat Rusts: An atlas of resistance genes. CSIRO, East Melbourne, Victoria 3002, Australia. pp 200.

18. McIntosh RA. 1988. The role of specific genes in breeding for durable stem rust resistance in wheat 
and triticale. In "Breeding Strategies for Resistance to the Rust of Wheat" (NW Simmonds and S Rajaram, eds.), CIMMYT, MexicoDF.pp. 1-9.

19. Peterson RF, AB Campbell and AE Hannah. 1948. A diagrammatic scale for estimating rust intensity of leaves and stem of cereals. Canadian Journal of Research 26: 496-500.

20. Prasad P, S Savadi, SC Bhardwaj and PK Gupta. 2020. The progress of leaf rust research in wheat. Fungal Biology 124: 537-550

21. Prasad P, SC Bhardwaj, OP Gangwar, S Kumar, H Khan, HC Rawal and TR Sharma. 2017. Population differentiation of wheat leaf rust fungus Puccinia triticina in South Asia. Current Science 112: 2073-2084

22. Pretorius ZA, RP Singh, WW Wagoire and TS Payne. 2000. Detection of virulence to wheat stem rust resistance gene Sr31 in Puccinia graminis f. sp. tritici in Uganda. Plant Diseases 84: 203.

23. Saari, EE, and JM Prescott. 1975. A scale for appraising the foliar intensity of wheat diseases. Plant Disease Reporter 5: 377-380.

24. Sai Prasad SV, SK Singh, Vinod, D Ambati, TL Prakasha, JB Singh, VG Dubey, SR Kantwa and AN Mishra. 2014. Introgression of stem rust resistance gene Sr36 into durum wheat back ground using marker assisted backcross breeding. Journal of Wheat Research 6:21-24.

25. Sharma AK, J Kumar and S Nagarajan. 1996. Report on coordinated experiments, 1995-96: Crop Protection. Directorate of Wheat Research, Karnal

26. Shiferaw B, M Smale, H Braun, Ee Duveiller, M Reynolds and G Muricho. 2013. Crops that feed the world 10. Past successes and future challenges to the role played by wheat in global food security. Food Security 5:291-317

27. Singh DP, AK Sharma, D Singh, SK Rana, KP Singh, K Srivastava,...... DS Dodan. 2009. Resistance to powdery mildew in Indian wheat. Plant Disease Research 24: 94.

28. Singh RP, DP Hodson, Y Jin, ES Lagudah, MA Ayliffe, S Bhavani et al. 2015. Emergence and spread of new races of wheat stem rust fungus: continued threat to food security and prospects of genetic control. Phytopathology 105: 872-884.

29. Singh RP, DP Hodson, J Huerta-Espino, Y Jin, S Bhavani, P Njau, S Herrera-Foessel, PK Singh, S Singh and V Govindan. 2011. The emergence of Ug99 races of the stem rust fungus is a threat to world wheat production. Annual Review of Phytopathology 49: $465-81$.

30. Singh RP, DP Hodson, J Huerta-Espino, Y Jin, P Njau, R Wanyera, SA Herrera-Foessel and WR Ward. 2008. Will stem rust destroy the world's wheat crop? Advances in Agronomy 98: 271-309

31. Stakman EC, DM Stewart, WQ Loegring. 1962. Identification of physiologic races of Puccinia graminis var tritici. Agricultural Research Service E617 United States Department of Agriculture, Washington.

32. The TT, BDH Latter, RA McIntosh, FW Ellison, PS Breman, J Fisher, GJ Hollamby, AJ Rathjen and RE Wilson. 1988. Grain yield of near-isogenic lines with added genes for stem rust resistance. In: Proc. $7^{\text {th }}$ Intern. Wheat Genet.Symp. (Eds.TE Miller and Koebner), IPSR, Cambridge, England. pp 901-906.

33. Third Advance Estimates. 2020. Directorate of Economics and Statistics (DES), Ministry of Agriculture and Farmers Welfare (MoA\&FW), India.

34. Tomar SMS, SK Singh, M Sivasamy and Vinod. 2014. Wheat rusts in India: Resistance breeding and gene deployment - A review. Indian Journal of Genetics and Plant Breed. 74: 129-156.

35. Tomar SMS and MK Menon, 2001. Genes for resistance to rusts and powdery mildew in wheat. Division of Genetics, ICAR-Indian Agricultural Research Institute, New Delhi. pp 45-64.

36. Tsilo TJ, Y Jin and JA Anderson. 2008. Diagnostic microsatellite markers for the detection of stem rust resistance gene Sr36 in diverse genetic backgrounds of wheat. Crop Science 48: 253-261.

37. Zadoks JC, TT Chang and CF Konzak. 1974. A decimal code for the growth stages of cereals. Weed Res. 14: 415-421 